\title{
Biochemical relationships with the orientation of the autotrophic dinoflagellate Gymnodinium breve under nutrient replete conditions
}

\author{
Daniel Kamykowski*, Edward J. Milligan, Robert E. Reed \\ Department of Marine, Earth \& Atmospheric Sciences, North Carolina State University, Raleigh, North Carolina 27695-8208, USA
}

\begin{abstract}
Swimming orientation in autotrophic marine dinoflagellates often follows a pattern attributed to positive phototaxis during the day and positive geotaxis at night. Exceptions that occur in field and laboratory observations most often describe ascents or descents that anticipate sunrise or sunset. These exceptions may originate in biochemical synthesis patterns that use sequential photosynthate (carbohydrate and lipid) production and dissolved nitrogen absorption for subsequent cell growth (RNA and protein) and division (DNA). instantaneous biochemical state may influence orientation either through mechanical ballasting or through growth optimization that influences sensory-mediated responses to environmental cues. In the present mesocosm $(150 \mathrm{~cm}$ length $\times 44 \mathrm{~cm}$ diameter) study, samples from a quantized (all cells divide together at approximately $3 \mathrm{~d}$ intervals) population of Gymnodinium breve Davis collected at the surface and mid-column support compansons of diel orientation preferences and cellular biochemical states over a $3 \mathrm{~d}$ period. Up to $50 \%$ of the column populathon aggregates at the surface during the day, but this percentage decreases with time since cell division. Within a given day, $G$. breve exhibits continuous negative geotaxis associated with surface aggregation when the taxis is stronger and with dispersion through the water column when the taxis is weaker. Positive phototaxis helps maintain surface aggregation during the afternoon as negative geotaxis weakens. The surface cells exhibit only slightly lower concentrations of DNA and RNA, somewhat lower concentrations of protein and carbohydrate, and significantly lower concentrations of chlorophyll $a$ and lipid, compared to the cells sampled from mid-column. The strength of the negative geotaxis of the mid-column cells negatively correlates with lipid concentration. These results support the case for a biochemical influence on orientation but require more experimental data to establish cause and effect.
\end{abstract}

KEY WORDS: Dinoflagellate Behavior · Biochemistry

\section{INTRODUCTION}

The investigation of phytoflagellate orientation in terms of sensory capabilities and taxes has an extensive literature (Levandowsky \& Kaneta 1987). Although these studies contribute significantly to current views of algal motility, they provide only a partial explanation of the complex behavior observed in the field (Harris et al. 1979) or in mesocosms (Macintyre et al. 1997). Dinoflagellates often accumulate at the surface during the day and descend or disperse through the upper water column at night. These migrations gener-

\footnotetext{
•E-mail: dan_kamykowski@ncsu.edu
}

ally correspond to taxes responsive to light and gravity, but the detailed patterns often are more complex than expected, as exemplified by frequently reported premature ascents or descents (Levandowsky \& Kaneta 1987) and by responses related to changing environmental conditions (Macintyre et al. 1997). Reconsideration of phytoflagellate diel vertical migration from both freshwater (Jones 1993) and marine (Kamykowski 1995) perspectives suggests that biochemical changes occurring over the cell cycle influence behavior. In the marine environment, interest in these biochemical patterns derives from studies of partitioned nutrition based on carbon fixation as carbohydrate (Cullen et al. 1985) near the surface during the day and nitrogen uptake (Blasco 1978) deeper in the water column at 
night (Cullen 1985), gyrotaxis (Mitchell et al, 1990) and the cell size and biosynthetic changes that accompany cell division (Berdalet et al. 1992, Latasa et al. 1992, Prezelin 1992). Alternate, but not mutually exclusive, hypotheses arise from this point of view. In one case, a purely mechanical effect occurs when photosynthate accumulation during the day (leading to ascent) and utilization at night (leading to descent) alter the lever arm moment of mass distribution relative to a cell's center of mass. In the other case, alternating accumulation and utilization of photosynthate and/or dissolved nutrient pools cross thresholds of biosynthetic need which in turn control sensory responses to environment cues. The purpose of this paper is to move beyond the theoretical exploration of biochemically mediated orientation (Kamykowski \& Yamazaki 1997, Kamykowski et al. 1998) to laboratory measurements of the taxis patterns and biochemical composition of a vertically migrating Gymnodinium breve population. Although $G$. breve is a Harmful Algal Bloom (HAB) dinoflagellate species from the Gulf of Mexico (Taylor \& Pollingher 1987), the results have impications for marine dinotlagellate behavior in general. Pertinent background information is provided next to provide a context for key elements of the experimental approach.

First, the present study gives special consideration to the cell division cycle of dinoflagellates. Most mesocosm studies of dinoflagellate behavior (see Kamykowski 1995) report results on phased populations in which a portion of the cells divide each day. Homma \& Hastings $(1988,1989)$ proposed a double filtration technique to quantize the cell division of dinoflagellates like Gonyaulax polyedra with generation times longer than $1 \mathrm{~d}$ so that all cells divide together as a population every few days. The quantized state achieved in the present experiment most likely results from the selection of behaviorally similar cells aggregated at the surface. Samples, collected here over a $3 \mathrm{~d}$ period immediately following a population doubling, measure successive diel expressions of behavior and biochemical composition in early-to-mid cell cycle under nutrient replete conditions.

Second, mesocosm studies of dinoflagellate behavior including this one typically use a profiling capability based on in vivo fluorescence (Cullen \& Horrigan 1981, Kamykowski 1981) and/or cell counts (Eggersdorfer \& Hader $1991 \mathrm{a}$, b) to monitor diel vertical migrations. Recent developments in laboratory chambers applied. to behavioral studies (Eggersdorfer \& Hader 1991a, b) and in motion analysis techniques (Kessler et al. 1992) also provide methods for the continuous evaluation of phytoflagellate orientation preferences related to light and gravity to supplement profiling. Because of occasional low cell numbers, the present study uses an incubation approach to taxes (Heil 1986) together with profiled diel vertical migration patterns to provide a more detailed perspective on dinoflagellate behavior.

Third, some past studies of dinoflagellate biochemical composition used gentle mixing to ensure an even cell distribution that eliminated behavioral separation (Berdalet et al. 1992) while a smaller number used laboratory mesocosms (e.g. Cullen \& Horrigan 1981, Heaney \& Eppley 1981) specifically to encourage the behavioral separation of cells (Eppley et al. 1968). In some cases, however, averages computed using samples from different depths were combined to represent the mesocosm as a whole (Cullen \& Horrigan 1981). Since the present study considers the sample depths independently without mixing as is typical in field observations, both diel patterns of cell biosynthesis and behavioral redistribution of the cells in response to diel vertical migration are active.

Finally, biochemical studies on marine organisms like dinoflagellates generally began with general constituents like carbohydrates, lipids and proteins (Chan 1978, Hitchcock 1982). More specific biochemical components (e.g. amino acids: Flynn et al. 1996; DNA and RNA: Berdalet et al. 1992; microsporine-like amino acids: Carreto et al. 1990; and photosynthetic pigments: Latasa et al. 1992) were considered as analytical techniques and specific physiological questions evolved. The present question, dealing with the relationship between biochemical constituents and orientation preference, examines both general (carbohydrate, lipid and protein) and more specific (chlorophyll a, DNA and RNA) components. These bulk biochemical measurements on the quantized population combine with cell counts to provide cell specific averages at a given depth and time.

\section{METHODS}

Culture techniques. Non-axenic, unialgal stock cultures of Gymnodinium breve Davis (Wilson isolate) were maintained in $125 \mathrm{ml}$ Erlenmeyer flasks filled with 34 psu seawater enriched to L1/2 medium (Guillard \& Hargraves 1993) except the Cu was eliminated and soil extract $\left(0.5 \mathrm{ml} \mathrm{l}^{-1}\right.$ obtained by autoclaving $100 \mathrm{ml}$ of Hyponex potting soil with $1 \mathrm{l}$ of deionized water) was added (i.e. modified-L1/2). The $20^{\circ} \mathrm{C}$ incubator was illuminated with fluorescent bulbs (mixed cool white and day light that provided $150 \mu \mathrm{mol}$ quanta $\mathrm{m}^{-2}$ $\mathrm{s}^{-1}$ PAR (photosynthetically active radiation) on a $12 \mathrm{~h}$ light: $12 \mathrm{~h}$ dark cycle. Larger volumes were grown in 201 carboys using modified-L $1 / 2$ medium, a temperature-controlled room set at $22^{\circ} \mathrm{C}$, and fluorescent bulbs (shoplite) that provided $200 \mu \mathrm{mol}$ quanta $\mathrm{m}^{-2} \mathrm{~s}^{-1} \mathrm{PAR}$ on a $12 \mathrm{~h}$ light: $12 \mathrm{~h}$ dark cycle. 
Mesocosm design. A translucent fiberglass column (155 cm length $\times 44 \mathrm{~cm}$ diameter, holding about $225 \mathrm{l}$ ) was washed with a weak $\mathrm{HCl}$ solution, rinsed with tap water, and then placed in a wooden frame positioned in a temperature-controlled room set at $22^{\circ} \mathrm{C}$. A $300 \mathrm{~W}$ tungsten-halogen lamp, suspended over the column, illuminated the column surface at about $400 \mu \mathrm{mol}$ quanta $\mathrm{m}^{-2} \mathrm{~s}^{-1}$ PAR through a $2 \mathrm{~cm}$ water bath heat filter with a sand-blasted $1 \mathrm{~cm}$ glass plate diffuser and neutral screens placed in the bottom of the bath. The column was filled simultaneously with pumped $0.2 \mu \mathrm{m}$ filtered seawater enriched to modified-L1/6 and gravity-fed cultures from the four 201 carboys. Samples were collected from the mesocosm using a weighted $5 \mathrm{~m}$ length of Tygon tubing $(0.32 \mathrm{~cm}$ inner diameter capable of collecting water from and returning water to the bottom of the mesocosm. The tubing outside the mesocosm looped through a peristaltic pump, entered and exited a Turner Designs fluorometer with a 5-60 excitation filter, a 2-64 emission filter and a FT45 blue lamp, and incorporated a Y-joint for water collection. Profiling, which occurred at a rate of $20 \mathrm{~cm}$ per $10 \mathrm{~s}$, disturbed but did not mix the column population, and the sampled cells remained motile after passage through the tubing. During profiling, the exit tube was positioned $10 \mathrm{~cm}$ below the entrance port to allow return to the approximate sample depth based on the transit time through the tubing. A thermistor connected to a Yellow Springs Instruments Co. control box was bound to the tubing in the mesocosm with the sensor at the depth of the inlet. Both the in vivo fluorescence and temperature at predetermined depths were digitized from line graphs obtained with a dual-channel WeatherMeasure chart recorder.

Schedule. Gymnodinium breve was first introduced into the mesocosm on 1 July 1997 with the uniform water column at an estimated $250 \mu \mathrm{M} \mathrm{NO}-\mathrm{N}$ (based on the initial inoculation of a L1/2 grown culture into L1/6 medium) and 600 cells $\mathrm{ml}^{-1}$. A $24 \mathrm{~h}$ sample set with collections every $4 \mathrm{~h}$ began at $02: 00 \mathrm{~h}$ on 2 July and ended at $02: 00 \mathrm{~h}$ on 3 July. The column then was left to cycle through the $12 \mathrm{~h}$ light: $12 \mathrm{~h}$ dark cycle in the temperature-controlled room for the next $8 \mathrm{~d}$ while the samples were analyzed. Interpretation of the biochemical patterns observed during the $24 \mathrm{~h}$ sample set required more detailed information on the population growth characteristics in the column. The column was renewed for the first time on 10 July by pumping out about $65 \%$ of the volume from the bottom while about half the cell population aggregated near the surface. This renewal was necessary because cell division rate slowed probably as a result of light limitation after the average population density reached about 4000 cells $\mathrm{ml}^{-1}$ The column then was refilled with filtered modified-L1/6 medium to an estimated $180 \mu \mathrm{M} \mathrm{NO}_{3}-\mathrm{N}$ [con- servatively based on adjustments for cell nitrate utilization ( $\mathrm{N}=$ protein/6.25) due to nitrate uptake only in the upper $12 \%$ of the mesocosm in the $35 \%$ residual and on $65 \%$ fresh media] and 1800 cells $\mathrm{ml}^{-1}$. Daily monitoring of the column occurred between 11 and 18 July with samples collected between 13:00 and 14:00 h. Both in vivo fluorescence profiles and discrete $10 \mathrm{ml}$ samples at $20 \mathrm{~cm}$ intervals for cell number determinations were collected. Cell counts on a $0.5 \mathrm{ml}$ volume were made on a Coulter Multisizer II Particle Analyzer with a $100 \mu \mathrm{m}$ orifice that was calibrated using $20 \mu \mathrm{m}$ polystyrene beads and that was blanked with the filtered seawater used to make the medium. On 19 July, about $75 \%$ of the column was withdrawn from the bottom for a second renewal while about half the cell population aggregated at the surface. The column then was refilled with filtered modified-L1/6 medium to about $150 \mu \mathrm{M} \mathrm{NO}_{3}-\mathrm{N}$ [conservatively based on adjustments for cell nitrate utilization $(\mathrm{N}=$ protein/6.25) due to nitrate uptake only in the upper $12 \%$ of the mesocosm in the $25 \%$ residual and on $75 \%$ fresh media] and 1400 cells $\mathrm{ml}^{-1}$. This water column was monitored with midday samples until the more intense $3 \mathrm{~d}$ sample set with in vivo fluorescence/temperature profiles every $2 \mathrm{~h}$ and water collection every $6 \mathrm{~h}$ began at 06:00 h on 22 July.

Water collection. During the $3 \mathrm{~d}$ experiment, water samples from the surface and mid-column $(\sim 0.75 \mathrm{~m}$ below the surface) of the $1.5 \mathrm{~m}$ mesocosm were collected at 6 h intervals into 2 separate 21 polycarbonate Fernbach flasks through the $\mathrm{Y}$-joint. The in vivo fluorescence and the temperature were recorded after the readings stabilized during the sample collection at each depth. A subsample was poured into a $125 \mathrm{ml}$ Erlenmeyer flask which then was placed briefly in the dark for subsequent cell number and taxis determinations. The remaining sample in the Fernback flask was divided into $100 \mathrm{ml}$ aliquots for either filtration (chlorophyll a and carbohydrate) or centrifugation (DNA, RNA, lipid and protein).

Taxes. See Kamykowski et al. (1988) for a picture of the basic design of the taxis units. Two nearly identical units adapted from that basic plan were used to monitor geotaxis and phototaxis. Six $20 \mathrm{ml}$ chambers $(4 \times 0.5$ $\times 10 \mathrm{~cm}$ ) constructed of black acrylic were suspended in a black acrylic box $(12 \times 6.5 \times 12.5 \mathrm{~cm})$ with attachment only at the surface and the slits set $1.3 \mathrm{~cm}$ apart. The box was connected to a thermostatically controlled water bath to control temperature in the $20 \mathrm{ml}$ chambers. A hollow cover $(12.5 \times 7.2 \times 1.2 \mathrm{~cm})$ was connected to the same thermostatically controlled bath as the box to control temperature from above the slits. The water-jacket cover for the geotaxis unit was made of black acrylic, and the unit was used with the slits facing upward. The water-jacket cover for the photo- 
taxis unit was made of clear acrylic, and the unit was used on its side (slit length dimension horizontal) with the slits facing a light source. A sub-cover of clear acrylic was used to seal the phototaxis unit after silicone grease was smeared on the slit-side surface of the box. Black tape was added over slits 3 and 4 on this sub-cover to provide a dark blank for these chambers, but these data were not used.

The phototaxis light source was a tungsten halogen projector lamp rated at $250 \mathrm{~W}$ but powered at only $80 \mathrm{~V}$. The PAR intensity at the surface of the cover ranged between 325 and $425 \mu \mathrm{mol}$ quanta $\mathrm{m}^{-2} \mathrm{~s}^{-1}$ due to light dispersion, but replicates dispersed across the PAR gradient all showed the same pattern. The spectrum of the projector lamp closely matched the spectrum of the growth light used over the $1.5 \mathrm{~m}$ migration column as measured with an Analytical Spectral Devices spectroradiometer. Both the surface and the mid-column samples from the migration column were exposed to the same PAR intensity in the phototaxis unit to facilitate intercomparisons between sample depths. The PAR exposure at night monitored the potential for phototaxis.

Aliquots from each depth were pipetted into successive triplicate slits in the geotaxis unit and into alternate triplicate slits in the phototaxis unit. After the small chambers were filled in both units, the geotaxis unit was covered with a black cloth to ensure darkness, the phototaxis unit was turned on its side with slits toward the light source, the projector lamp was turned on, and a stopwatch was started. After $25 \mathrm{~min}$, the projector lamp was turned off, the phototaxis unit was turned slit-side up, and each small chamber in the phototaxis unit was emptied with a disposable pipette into 3 scintillation vials representing the upper, middle and lower thirds, respectively. After $35 \mathrm{~min}$, the geotaxis unit was emptied similarly. The vials (about $6.7 \mathrm{ml}$ in each) were counted using the Coulter Multisizer II Particle Analyzer, and the cell number and average cell size in each vial were recorded in the 14 to $28 \mu \mathrm{m}$ diameter band.

Biomass estimates. For cell number determinations, three $6 \mathrm{ml}$ subsamples were poured into $20 \mathrm{ml}$ scintillation vials for cell counts and cell size determinations using the Coulter Multisizer II Particle Analyzer. Since the fluorescence determinations accurately represented the cell counts $\left(r^{2}=0.94\right)$, the cell content of the column was calculated by extrapolating the cell counts from the surface and the mid-column depths to the whole column based on the in vivo fluorescence profile. To maintain a uniform calculation, this approach was applied on all sample days reported in this paper even if more sample depths were available on a given day. The in vivo fluorescence profile was interpreted as a water column composed of upper and lower strata that varied in thickness with time of day. The water samples were withdrawn without replacement of the volume in the column. No correction was made for this loss in the daily counts made between 19 and 21 July because the volume removed was relatively small $\left(<200 \mathrm{ml} \mathrm{d}^{-1}\right)$. However, the volume removed between 22 and 25 July was about 41 every $6 \mathrm{~h}$. To correct for this greater loss, the removed cells were added back mathematically to obtain a running tally of the column total.

For chlorophyll a determinations (Parsons el al. 1984), triplicate $100 \mathrm{ml}$ subsamples were collected and processed through GF/F filters with the vacuum set at 10 inches $(254 \mathrm{~mm})$ of $\mathrm{Hg}$. After dark storage in $10 \mathrm{ml}$ of $90 \%$ acetone at $-20^{\circ} \mathrm{C}$ for $24 \mathrm{~h}$, samples were read before and after $\mathrm{HCl}$ acidification on a Turner fluorometer with a NB440 excitation filter, a SC665 emission filter, and a tungsten-halogen lamp. The instrument was calibrated with commercial chlorophyll a (Sigma C-5753).

Biochemistry. Carbohydrate analysis was adapted from Dubois (1956). A $100 \mathrm{ml}$ subsample was filtered through an ashed $G F / D$ filter previously wrapped in foil and baked at $450^{\circ} \mathrm{C}$ for a minimum of $8 \mathrm{~h}$. Sample filters were stored frozen in individual $15 \mathrm{ml}$ polyethylene centrifuge tubes. Standards were prepared from a dilution series of dextrose solution $\left(200 \mathrm{mg} \mathrm{m}^{-1}\right.$ distilled $\mathrm{H}_{2} \mathrm{O}$ ) made up to $2 \mathrm{ml}$ in glass tubes. For samples, $2 \mathrm{ml}$ of distilled water were added to the filters after they were transferred to glass tubes. Samples and standards then were modified with $1 \mathrm{ml}$ of $5 \%$ phenol solution and by the slow addition of $5 \mathrm{ml}$ of concentrated sulfuric acid inside a fume hood. Samples were mixed and allowed to stand at room temperature for $45 \mathrm{~min}$. Tubes then were centrifuged at $2650 \mathrm{rpm}$ $(\sim 1200 \times g)$ for 10 min to clarify the samples and the absorbance of the supernatant was read at $485 \mathrm{~nm}$ with distilled water as the blank using $1 \mathrm{~cm}$ quartz cuvettes in a Bausch \& Lomb Spectronic 601 spectrophotometer.

Lipid analysis followed the procedure of Kochert (1978). A $100 \mathrm{ml}$ subsample distributed in two $50 \mathrm{ml}$ centrifugation tubes was spun at $2650 \mathrm{rpm}(\sim 1200 \times \mathrm{g})$ for $10 \mathrm{~min}$. This centrifugation rate was toward the high end of the force (200 to $1500 \times g$ ) and time (5 to $10 \mathrm{~min}$ ) recommended in Kemp et al. (1993) for phytoplankton. The supernatant was poured or pipetted off until a few ml remained, the pellets were resuspended, and the suspensions were combined in a $15 \mathrm{ml}$ polyethylene centrifuge tube and stored frozen. For analysis, storage tubes were thawed and re-centrifuged to form a new pellet that was used for analysis. Briefly, the pellet was transferred to a glass test tube using the first wash with cold dilute perchloric acid. It was iced prior to the second wash with cold dilute perchloric acid which was followed by duplicate chloroform/methanol extractions 
that were combined after centrifugation. After a water wash, the aqueous layer was removed and the organic layer was reduced to dryness by vacuum evaporation. After exposure to dichromate at $100^{\circ} \mathrm{C}$ for $45 \mathrm{~min}$, the sample was cooled and the absorbance at $350 \mathrm{~nm}$ was read using $1 \mathrm{~cm}$ quartz cuvettes on a Bausch \& Lomb Spectronic 601 spectrophotometer Palmitic acid was used as the lipid standard.

The protein analysis used the Sigma Diagnostics protein assay kit (Procedure No. P 5656) based on Lowry et al. (1951) as modified by Peterson (1977). Briefly, the pellet obtained by centrifugation as described for lipid was suspended in $1 \mathrm{ml}$ distilled water to which $0.1 \mathrm{ml}$ of sodium deoxycholate solution and $0.1 \mathrm{ml}$ of trichloroacetic acid were added to induce precipitation to isolate the protein from contaminants. After centrifugation, the pellet was dissolved in $1 \mathrm{ml}$ of modified Lowry reagent (alkaline cupric tartrate). After a 20 min incubation to complex with the peptide bond, phenol was added to form a purple color read after $30 \mathrm{~min}$ at $750 \mathrm{~nm}$ using disposable $1 \mathrm{~cm}$ acrylic cuvettes in a Bausch \& Lomb Spectronic 601 spectrophotometer. Bovin serum albumin was used as the protein standard.

Analyses for RNA and DNA were adapted from the procedures described in Berdalet \& Dortch (1991). Briefly, the pellet obtained by centrifugation as described for lipid was suspended in $1 \mathrm{ml}$ Tris buffer and sonicated. An additional $1 \mathrm{ml}$ of Tris buffer was then added to the sample which then was centrifuged. The supernatant was divided and treated as described by

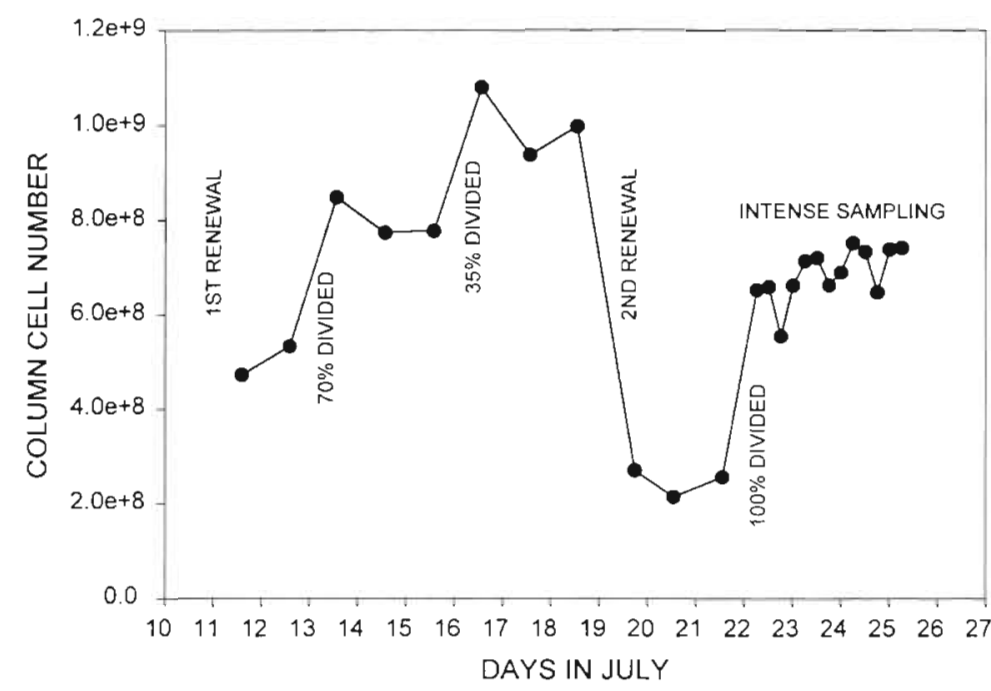

Fig. 1 Gymnodinium breve. Estimated number of cells in the column after the first column renewal from 11 to 18 July with daily samples showing the population divided twice $(70 \%$ and $35 \%)$ and after the second column renewal from 19 to 25 July with 3 daily samples prior to a cell division $(100 \%)$ followed by 13 more intense samples every 6 h. The caption 'Intense Sampling' identifies the time period covered by the data presented in this paper
Berdalet \& Dortch (1991) to determine blank fluorescence, total nucleic acid [Thiazole orange (TO) fluorescence; exitation: NB490, emission: SC515] and DNA [Hoechst (HO) fluorescence; exitation: NB360, emission: SC430] on a Turner fluorometer with a tungstenhalogen lamp. The chosen wavelengths were the closest available to those suggested. DNA standards were determined for both $\mathrm{HO}$ and TO fluorescence while RNA standards only were determined for TO fluorescence.

Analysis. The data were plotted and analyzed using Microsoft Excel, SigmaPlot and SigmaStat. Error bars are reported as 1 standard deviation.

\section{RESULTS}

During the daily monitoring sequence following the first renewal, cell number increased by about $70 \%$ on 13 July and by $35 \%$ on 17 July (Fig. 1). Based on this cell division at about $3 \mathrm{~d}$ intervals, the column was renewed for the second time on 19 July and monitored for 2 more days with the expectation that a cell division would occur during the night of 22-23 July. Essentially all of the cells in the column divided at that time (Fig 1). The limited precision of the whole column estimation technique contributed to the variation in the cell numbers on the days before and after the division. The slow upward trend after 22 July suggested cell division in a very small percentage of the population over the 3 sample days.

A portion of the column population migrated to the surface each of the 3 days as demonstrated by separate in vivo fluorescence readings obtained at the surface and mid-column every $6 \mathrm{~h}$ at water collection (Fig. 2). Since the pattern at noon each day suggested a higher surface concentration on the first day, equaling about half the cells in the column, compared to Days 2 and 3, the strength of surface aggregation apparently decreased with time since last division. At night, the column population evenly dispersed through the water column.

Cell diameter was the same at the surface and at mid-column at a given time of day (Fig. 3). It increased about $7 \%$ from 06:00 to 18:00 $\mathrm{h}$, leveled off from 18:00 to $24: 00 \mathrm{~h}$ and decreased abruptly by $7 \%$ from $24: 00$ to $06: 00$ h each day. In the present case, the observed change in cell diameter was independent of cell division.

Cell counts and diameters from the geotaxis and phototaxis units exhibited confidence limits that were similar to those re- 


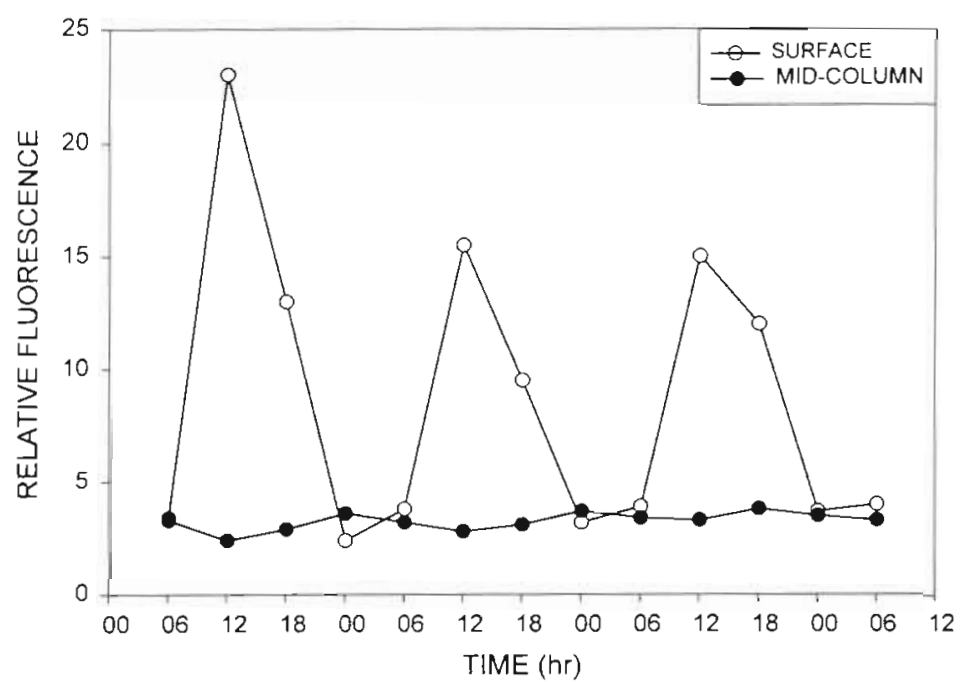

Fig. 2. Gymnodinium breve. In vivo fluorescence values recorded while filling the Fernbach flasks at water collection from surface and mid-column depths during the intense sampling at $6 \mathrm{~h}$ intervals from 22 to 25 July

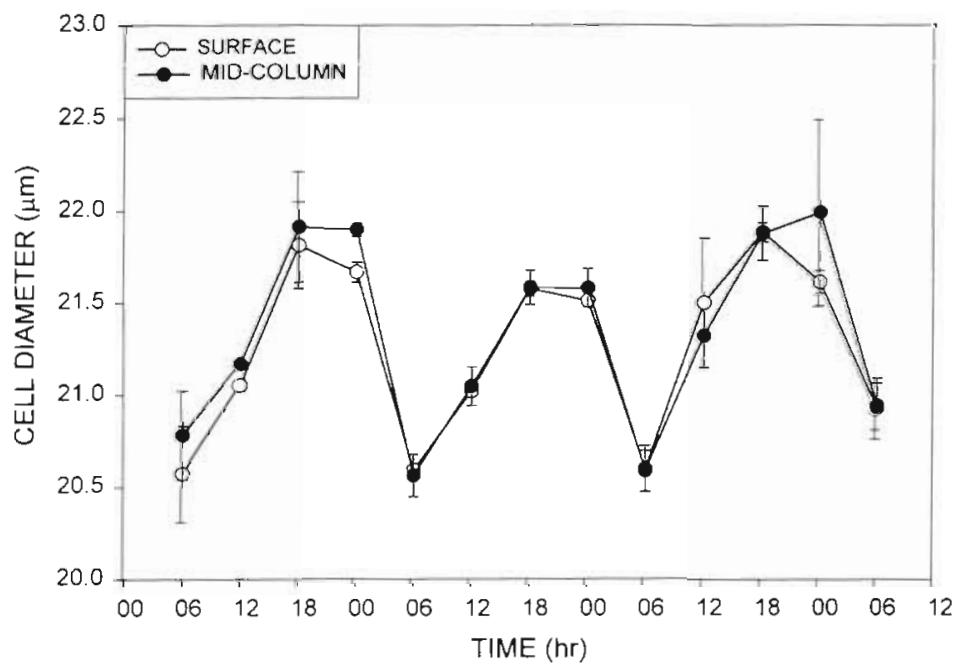

Fig. 3. Gymnodinium breve. Changes in cell diameters from surface and mid-column depths during the intense sampling at 6 h intervals

from 22 to 25 July. Error bars represent \pm 1 standard deviation

ported for column determinations of population density. The percentage of surface and mid-column cells observed in each third of their respective chambers monitored the occurrence and sign (positive or negative) of geotaxis and of phototaxis. If there is no preferential motion, about $33 \%$ of cells should occur in each third at the time of measurement. The geotaxis percentages often approached $33 \%$ in each third of the chamber at $18: 00 \mathrm{~h}$ and the phototaxis percentages hovered around $33 \%$ in each third of the chamber except at 12:00 h. Values from the upper third of the chambers in Fig. 4 provide a comparison with Gymnodinium breve's diel vertical migration. Negative geotaxis $1>33 \%$, as marked by the solid line) in the surface population was strong at 00:00, 06:00 and 12:00 h but weaker at 18:00 h. Negative geotaxis in the mid-column population was strongest at 06:00 h. The surface cells probably occurred at the surface at night because of this tendency for negative geotaxis while the mid-column cells moved up toward the surface in the morning. Variability in the strength of negative geotaxis declined over the course of the 3 days as the overall strength uniformly increased at both depths: Positive phototaxis $(>33 \%$, as marked by the dashed lines) showed the same pattern at both sample depths. The sample frequency limited detection to noon, and taxis strength increased over the 3 days. Timing of the mid-column positive phototaxis occurred after the peak in negative geotaxis and temporarily reinforced the near-surface location of the cells. The increasing strength of both taxes over the $3 \mathrm{~d}$ period contrasts with the observation that the strength of the surface accumulation in the growth column decreases over the 3 days. The mechanical disturbance of the cells that is inherent in the taxis measurement may strengthen the ascent response of cells that otherwise remain more dispersed in the water column. Strong surface re-aggregation visually observed after the disturbance imposed by column profiling adds support to this hypothesis.

The biochemical constituents divided into 3 groups based on differences between the surface and mid-column samples. In the first group, DNA (Fig. 5A) and RNA (Fig. 5B) concentrations often were similar between depths but surface values averaged 23 and $13 \%$ lower at $12: 00 \mathrm{~h}$, respectively. In the second group, carbohydrate (Fig. 5C) and protein (Fig. 5D) concentrations were routinely lower at the surface during the day; they averaged 16 and $27 \%$ lower at $12: 00 \mathrm{~h}$, respectively. In the third group, chlorophyll a (Fig. 5E) and lipid (Fig. 5F) concentrations were consistently lower at the surface during the day; they averaged 47 and $74 \%$ lower at $12: 00$ h, respectively. Although this column population exhibited quantized cell division, it apparently did not similarly synchronize biochemical composition over the light/dark cycle. The column was most uniform biochemically between 24:00 and 06:00 $h$ when the cells were distributed evenly throughout the column. The oscillatory pattern in biochemical composition probably was influenced by the diel biosynthetic patterns and the behavioral redistribution of cells in the water column with time. All of the constituents increased in average cellular concentration over the $3 d$ period except lipid which decreased. 


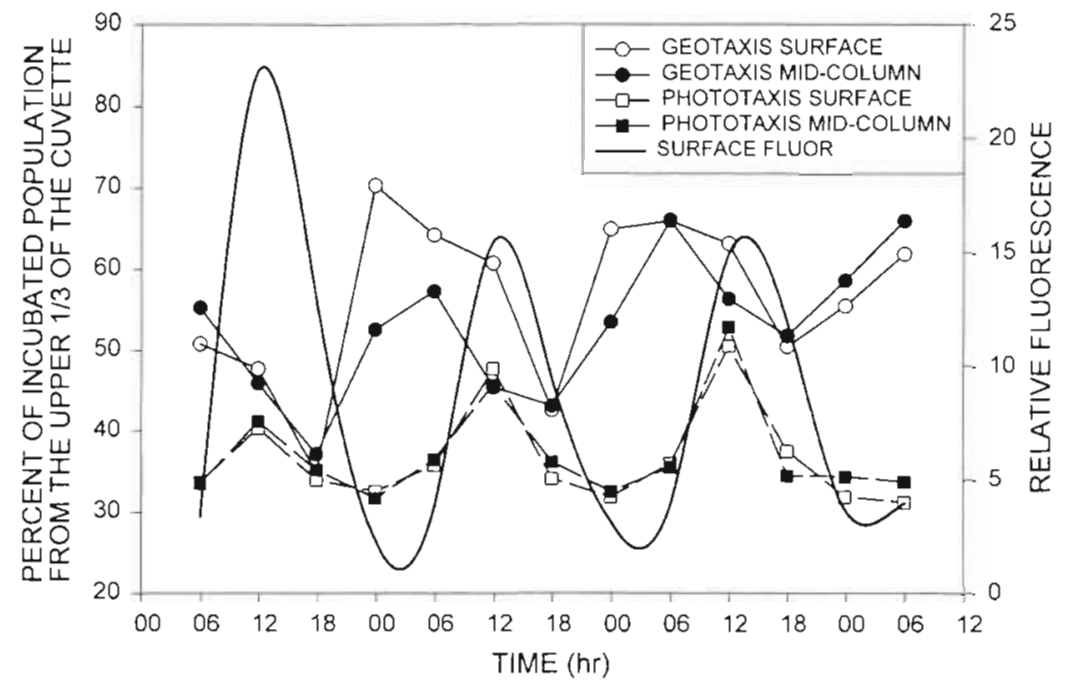

Fig. 4. Gymnodinium breve. A comparison of the time course of in vivo fluorescence (spline fit to $6 \mathrm{~h}$ data represented by curved line without symbols) with the percentages for the upper third of the geotaxes and phototaxis units for mesocosm surface and mid-column samples

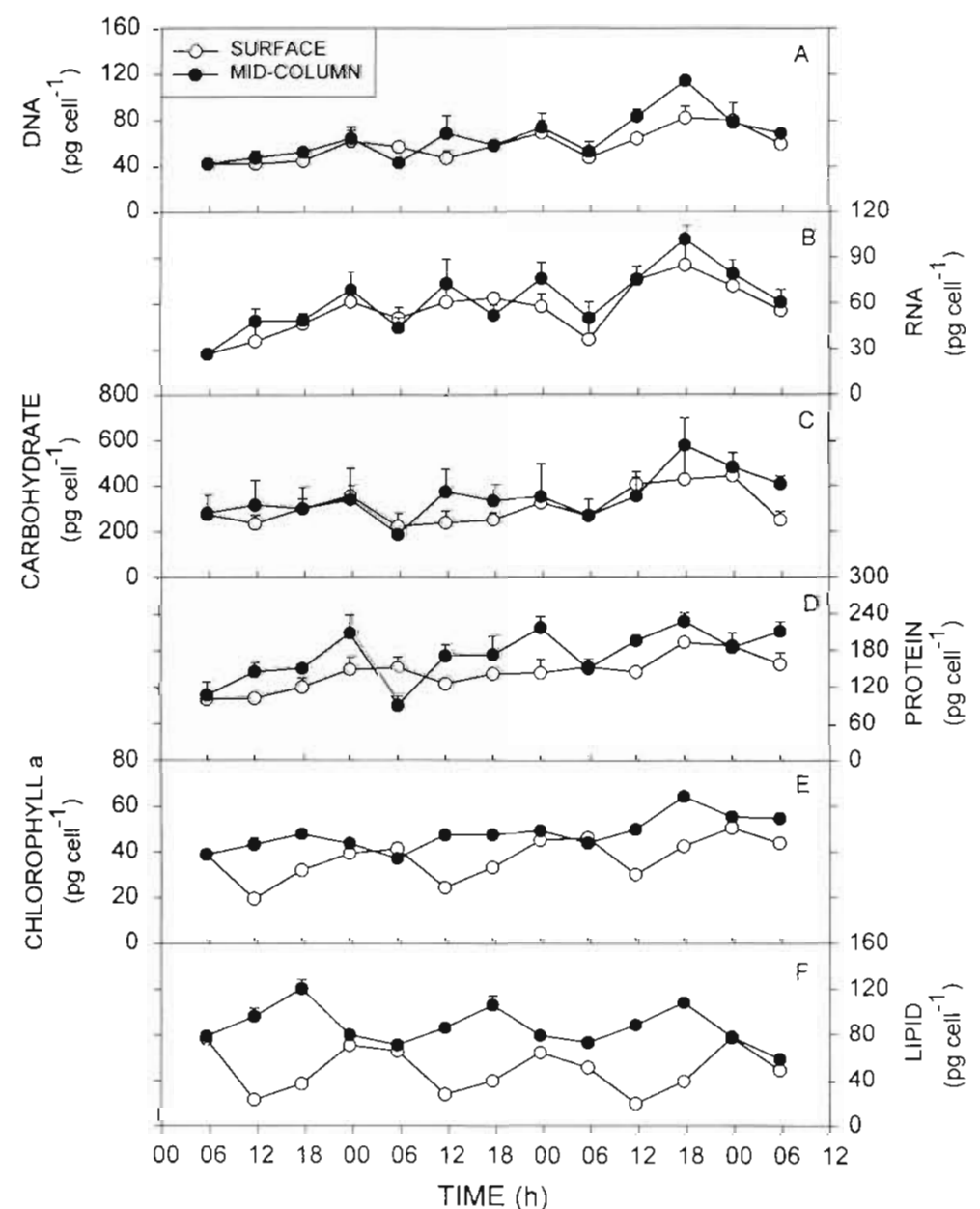

Fig. 5. Gymnodinium breve. Time course of (A) DNA, (B) RNA, (C) carbohydrate, (D) protein, (E) chlorophyll a and (F) lipid for surface and midcolumn mesocosm samples. Error bars are +1 standard deviation
The ratio formed by dividing the surface value by the mid-column value at a given time divides the measurements into 2 groups based on the regularity of the cycles. The DNA-RNA-carbohydrate triplet (Fig. 6A) varies between 0.65 and 1.35 , with 7 out of 39 values above 1.0. The synchrony that exists among these components in the first $24 \mathrm{~h}$ decreases in the subsequent $48 \mathrm{~h}$. The protein-chlorophyll a-lipid triplet (Fig. 6B) varies between 0.20 and 1.55 of the mid-column concentration, with 5 out of 39 values above 1.0. These components maintain synchrony throughout the data set.

In order to highlight the biosynthetic sequence over a $24 \mathrm{~h}$ period, the samples collected at a given time of day were averaged, and each average was divided by the maximum from the group (Fig. 7). Also, an RNA/DNA ratio (Berdalet \& Dortch 1991) was added to the data set. In the surface set (Fig. $7 \mathrm{~A}$ ), this ratio peaks and leads all other measurements at 12:00 h. RNA increases through the light period, peaking at 18:00 h. Carbohydrate and DNA increase continuously from 06:00 to 24:00 h. Chlorophyll a, protein and lipid all decrease between $06: 00$ and $12: 00 \mathrm{~h}$ and then increase between $12: 00$ and 24:00 h. These patterns suggest that components required for subsequent biosynthesis (RNA and carbohydrate) build-up before the dependent pools (chlorophyll $a$, protein, DNA and lipid) begin to increase. At midcolumn (Fig. 7B), the different organic pools are better synchronized, with almost all peaking between 18:00 and 24:00 h. A major discrepancy is the significant lipid decrease at 24:00 $\mathrm{h}$. The RNA/DNA ratio generally follows the overall pattern of the other biochemical components except for a somewhat lower value at 18:00 h. This pattern does not suggest a synthetic sequence.

The strength of the negative geotaxis in the surface and the mid-column populations was compared to the cell concentration of the measured biochemical constituents. The strongest relationship (Table $1 ; r=-0.85$ ) is in the mid-column sample set where the strength of negative geotaxis correlates inversely with lipid concentration (Fig. 8) over the concentration range from 60 to $120 \mathrm{pg}$ cell $^{-1}$. The relationship is much weaker at the 

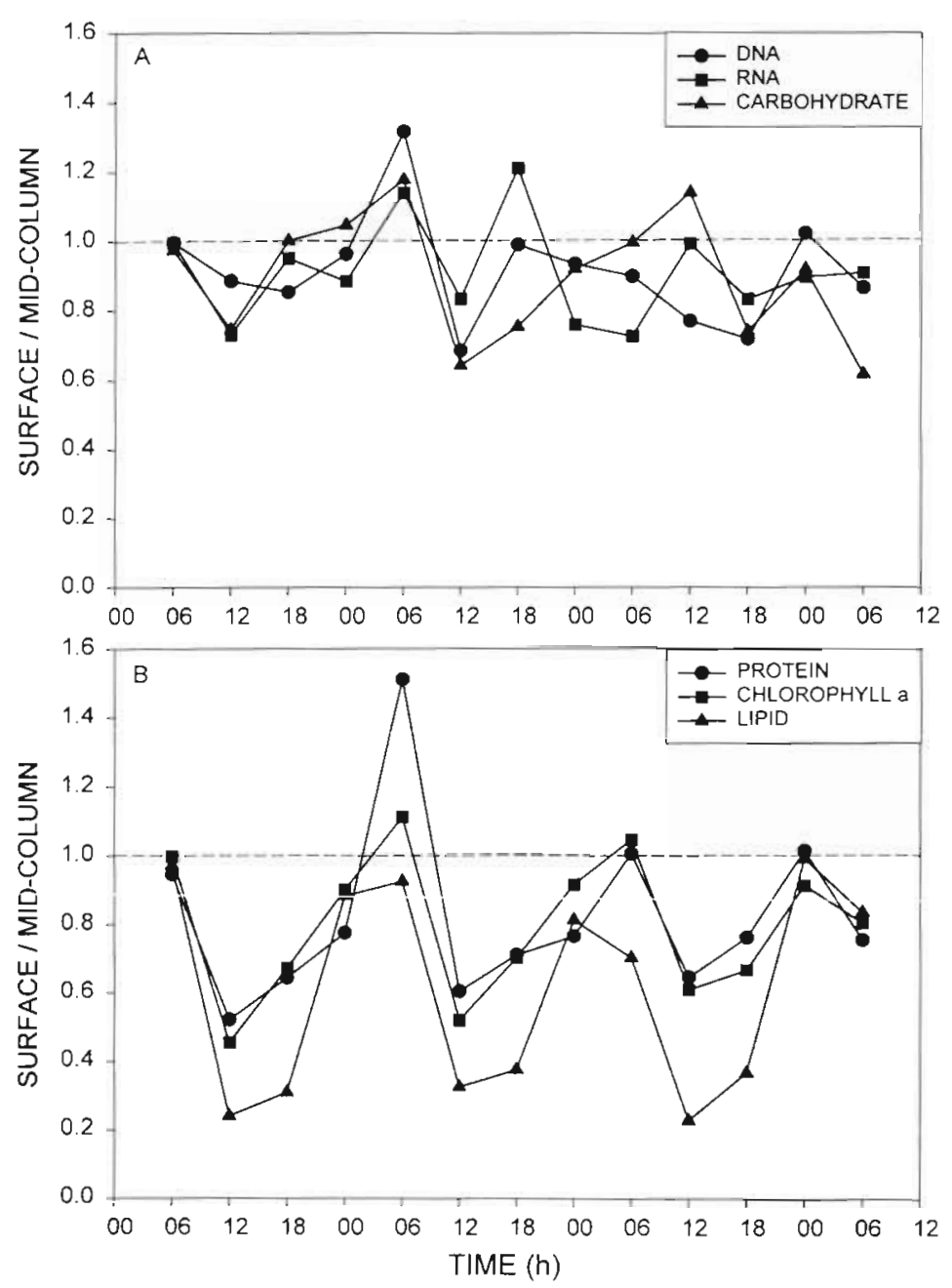

Fig. 6. Gymnodinium breve. Time course of surface/mid-column ratios for (A) DNA, RNA and carbohydrate, and (B) protein, chlorophyll $a$ and lipid. Dashed line marks equal concentrations at both sample depths

to light limitation, a substantial volume of the column was withdrawn from the bottom during mid-afternoon after the surface aggregation formed. After 2 renewals, the population maintained a $3 \mathrm{~d}$ doubling time but assumed quantized growth with all of the cells dividing together on the same day. Sournia's (1974) review of circadian periodicities supports speculation that the column renewals selected a cell cycle stage that aggregated near the surface of the column at the time of withdrawal. Frempong's (1982) observation that phased cell division in Ceratium hirundinella predominantly occurred in cells that did not descend at night probably describes a related phenomenon. This isolation of cells in a similar phase of the cell cycle behaviorally accomplishes the same result as the filtration of different cell sizes as demonstrated for Gonyaulax polyedra by Homma \& Hastings (1988, 1989). For present purposes, the quantized growth pattern provides an opportunity to study ceilular biochemistry using bulk chemical analyses. This simple behaviorally mediated induction of quantized growth also raises the possibility that similarly phased field populations may result from physical separation of surface populations by current shear. Under the proper circumstances, a single quantized cell division within $1 \mathrm{~d}$ may raise $G$. breve's population density above the threshold required for obvious ecosystem impact and may lead to the sudden appearance of a HAB (Tester \& Steidinger 1997).

Berdalet et al. (1992) noted a similar overnight pattern of change in cell diameter as surface $(r=0.32)$ where lipid concentration ranges from 20 to $80 \mathrm{pg} \mathrm{cell}^{-1}$. As seen in Fig. 7 A, surface cells exhibit decreasing lipid concentration until noon and increasing lipid concentration through midnight. The maximum lipid at the surface is near the minimum at depth and the surface peak lags that at mid-column by $6 \mathrm{~h}$ (Fig. 5F).

\section{DISCUSSION}

During the days immediately following inoculation into the mesocosm, the Gymnodinium breve population with a doubling time of about $3 \mathrm{~d}$ was phased. That is, a portion of the population in the column divided each day around the time of lights-on when grown under nutrient replete conditions on a $12 \mathrm{~h}$ light:12 h dark cycle. In order to renew the mesocosm after several days of growth that slowed probably due observed here for Gymnodinium breve. The cell diameter of Heterocapsa sp. changed about $20 \%$, while that cases, however, the significant number of cell divisions that occurred each night likely contributed to the

Table 1. Correlation coefficients between surface and midcolumn geotaxis percentages as presented in Fig. 4 and the measured biochemical constituents as presented in Fig. 5. Bold number designates significance at the $5 \%$ level

\begin{tabular}{|lcc|}
\hline & Surface geotaxis & Mid-column geotaxis \\
\hline Carbohydrate & 0.08 & 0.04 \\
Chlorophyll a & 0.37 & 0.06 \\
DNA & 0.24 & 0.09 \\
DNA/RNA & -0.07 & -0.12 \\
Lipid & 0.32 & $-\mathbf{0 . 8 5}$ \\
Protein & 0.47 & -0.09 \\
RNA & 0.13 & 0.05 \\
\hline
\end{tabular}
of Olithidiscus luteus changed about $14 \%$. In those 

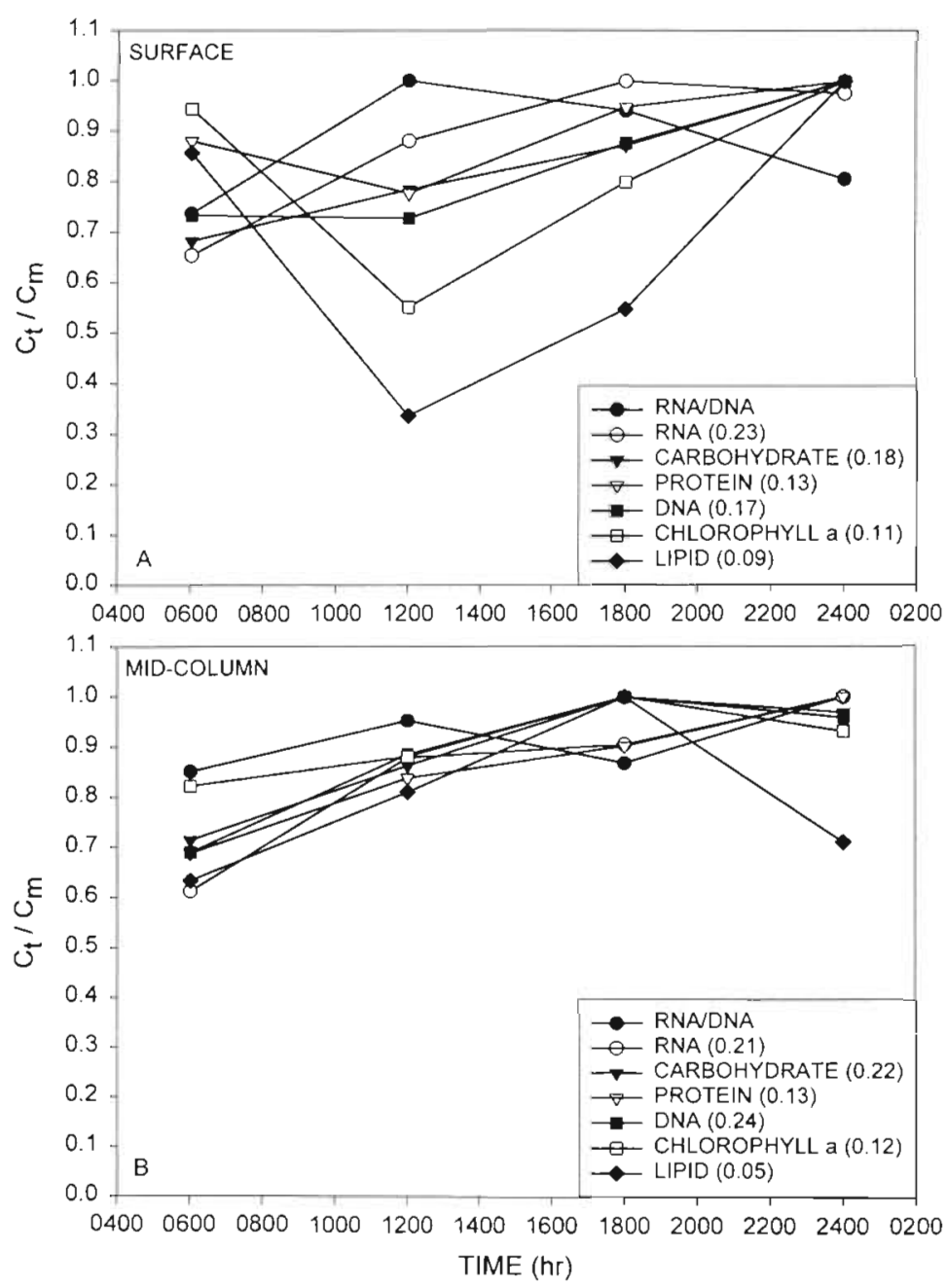

Fig. 7 Gymnodinium breve. Time course of surface and mid-column multi-day averages $\left(C_{t}\right)$ for each constituent and the RNA/DNA ratio at 06:00, 12:00, 18:00 and 24:00 h from Fig. 5 normalized to the maximum average value $\left(C_{m}\right)$ for that constituent. Legend values in parentheses are standard deviations of averages spherical diameter of $20 \mu \mathrm{m}$, like Gymnodinium breve, sinks at a rate of about $1 \mathrm{~m} \mathrm{~d}^{-1}$. This translates to about $2.5 \mathrm{~cm}$ in $35 \mathrm{~min}$, or about $25 \%$ of the height of a $10 \mathrm{~cm}$ high geotaxis chamber. This sinking rate should appear as a positive geotaxis. Significant positive geotaxis or negative phototaxis, detected as $>33 \%$ in the lower third of the respective chambers, never occurred for $G$. breve.

Gymnodinium breve's persistent negative geotaxis that weakened at the end of the light period and its middle light period positive phototaxis that disappeared at other times generally coincided with surface aggregation during the midday and dispersion through the water column at night. This behavior contrasts with Heterocapsa illdefina as measured in our taxis units or with other species reported in the literature (Eggersdorfer \& Hader 1991a, b). Some of these other species exhibit strong positive geotaxis and/or negative phototaxis at night and are capable of a synchronized descent at night that leads to subsurface peaks in abundance. The measured taxes for $G$. breve provide a standard behavioral index to compare with cellular biochemical components measured at different depths in the water column.

The necessity of using non-axenic cultures to grow Gymnodinium breve (G. J. Kirkpatrick pers. comm.) raises the question of whether the reported cellular concentrations of the biochemical constituents really represent $G$. breve. Visual observation of the culture suggested that bacterial abundance was low and that $G$. breve dominated the biomass especially during the surface aggregations. In changes in average cell size. Since the reported values are based on 'equivalent spherical diameter' determined with a Coulter Multisizer II Particle Analyzer, we cannot distinguish between cell shrinkage and changes in cell shape as the cause of the observed size changes in $G$. breve in the absence of significant cell division.

From the relationship reported in Kamykowski et al. (1992), a cell with an equivalent

Fig. 8. Gymnodinium breve. Percentage from the upper third of the geotaxis chamber vs lipid content of the cells collected at the same time for surface and mid-column mesocosm samples. Dashed line represents the surface regression, while solid line represents the mid-column regression

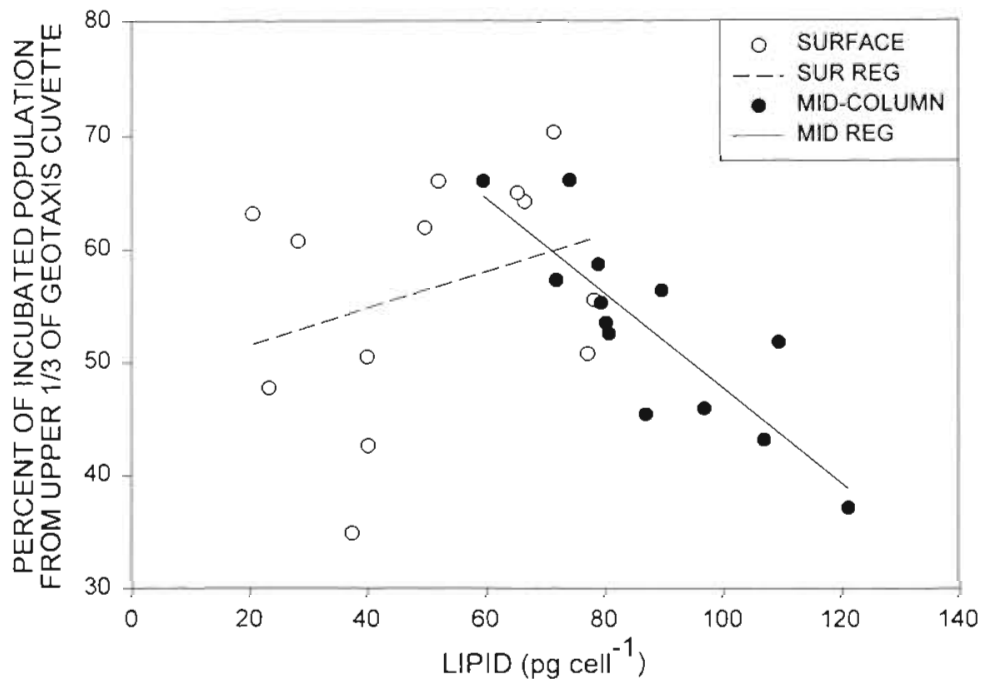


terms of the chosen methods, the nominal filter pore size was $0.7 \mu \mathrm{m}$ for chlorophyll a because $G$. breve was the only autotroph but a much larger $2.7 \mu \mathrm{m}$ for carbohydrate, with lower filtration efficiency for small particles like bacteria. Also, the 10 min centrifugation time was sufficient to harvest $G$. breve, but would be less efficient for the smaller bacteria. Kemp et al. (1993) recommend $4000 \times g$ for $20 \mathrm{~min}$ as appropriate for harvesting bacteria compared to the $1200 \times g$ for $10 \mathrm{~min}$ used here. A quantitative comparison with the predictions of dinoflagellate log-log regression relationships reported by Hitchcock (1982) for chlorophyll a, carbohydrate, protein and lipid using an estimated $G$. breve cell volume of $2000 \mu \mathrm{m}^{3}(20 \times 20 \times 5 \mu \mathrm{m})$ yields values of measured/predicted of $3.23,1.85,0.32$, and 0.43 , respectively. Since these ratios are within the scatter leading to Hitchcock's regression relationships, a significant dinoflagellate signal is supported. Note that $G$. breve's component ratios deviate from the average dinoflagellate in an apparently unbalanced way. Until more experimental data are available, the observed ratios are considered normal for this species. Since $G$. breve was the only autotroph in the mesocosm, the similarity of the chlorophyll a pattern to some of the other constituents provides a strong case for the application of the biochemical results to $G$. breve.

According to Rizzo et al. (1982), haploid Gymnodinium breve cells contain $113 \mathrm{pg}$ cell ${ }^{-1}$ of DNA. This concentration generally agrees with the average of $102 \mathrm{pg} \mathrm{cell}{ }^{-1}$ measured by Kim \& Martin (1974) and with the average of $110.41 \pm 22.13 \mathrm{pg} \mathrm{cell}^{-1}$ measured during the $24 \mathrm{~h}$ observation on the definitely nonquantized 2-3 July population. The DNA concentration in the 22-25 July quantized. G. breve population averaged only $62.20 \pm 17.11 \mathrm{pg} \mathrm{cell}{ }^{-1}$. This concentration is near the lower values reported by Kim \& Martin (1974) when salinity was near the optimum of 35 psu. Since the RNA concentrations measured at the 2 different times in July averaged $58.66 \pm 11.94$ and $59.52 \pm$ $18.13 \mathrm{pg} \mathrm{cell}^{-1}$, respectively, the basic nucleic acid technique seems consistent. If so, the newly divided cells in the quantized population have a DNA content near $50 \mathrm{pg} \mathrm{cell-1}$ and some cells approach $100 \mathrm{pg}^{-1}$ cell $^{-1}$ by the third day. Karentz (1983) described several possible patterns of DNA synthesis relative to cell division for different dinoflagellate species. For the quantized G. breve population, DNA synthesis appears to be uncoupled from cell division and may be continuous as reported for a few other dinoflagellate species. Karentz (1983) identified this type of DNA synthesis as a prokaryotic trait symptomatic of rapidly growing cells.

As previously stated, the measured biochemical patterns include both diel synthesis sequences and the behavioral redistribution of the cells. All of the cells in the mesocosm followed the same cell size oscillation corresponding to a photosynthesis-related maximum at 18:00 $\mathrm{h}$ and a respiration-related minimum at 06:00 h. Nevertheless, the cells did not all follow the same behavior. In general, the cells at the surface and mid-column were biochemically very similar at 06:00 h, when the population was evenly distributed throughout the water column. Over the 3 days of sample collection, 47,38 and $33 \%$ of the cells in the column aggregated at 12:00 $\mathrm{h}$ in a near-surface volume that represented about $12 \%$ of the column. Since Gymnodinium breve is capable of swimming vertically about $1 \mathrm{~m} \mathrm{~h}^{-1}$ (Heil 1986), the cells that did not accumulate at the surface certainly were capable of doing so. The DNA and RNA concentrations in the surface cells often were similar to, but occasionally lower than, those found at mid-column at 12:00 and 18:00 h. The carbohydrate, protein, chlorophyll $a_{1}$ and lipid concentrations in these cells routinely were lower than those found at mid-column at 12:00 and 18:00 h. Chlorophyll $a$ is a special case since photoacclimation can influence cellular concentration. The lower concentration of chlorophyll at the surface compared to mid-column could be interpreted as a response to higher PAR intensity. With the available data, we are unable to distinguish between uneven allocation of chloroplasts at cell division and photoacclimation as the cause.

An explanation of the observed behavioral and biochemical patterns begins with the starting conditions that all of the cells in the column divided sometime between 12:00 h on 21 July and 06:00 h on 22 July, and then the population essentially did not divide over the next $3 \mathrm{~d}$. As previously stated, the average cellular diameter and biochemical composition at the surface and mid-column were nearly identical at $06: 00 \mathrm{~h}$ on 22 July. An important question is why the cell populations at these 2 depths exhibit the subsequent biochemical divergences on the 3 sample days. Unfortunately, the answer begins with an unknown. Were the individual parent $(P)$ and/or the resulting daughter (D) cells biochemically the same (s) or different (d) at the time of division? These conditions yield 4 possibilities, Ps-Ds, Ps-Dd, Pd-Ds and Pd-Dd, as displayed in Fig. 9 for the simple case of 2 cell types. In reality, a continuous spectrum of different types of cells may exist based on how the 'different' category is defined. In. order to yield the daily biochemical divergences measured, PsDs requires that different cells attain the surface at different times (temporal mechanism), possibly because cells that start deeper in the water column at lights-on arrive later. After a rapid gain of biochemical constituents at the surface, the early arrivals descend from the surface while the late arrivals with lower biochemical concentrations continue to aggregate at the surface through the light period. In this dynamic situation, the cells contributing to the surface aggregation may 

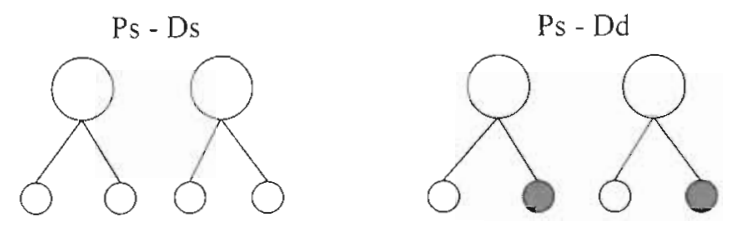

$\mathrm{Pd}-\mathrm{DS}$
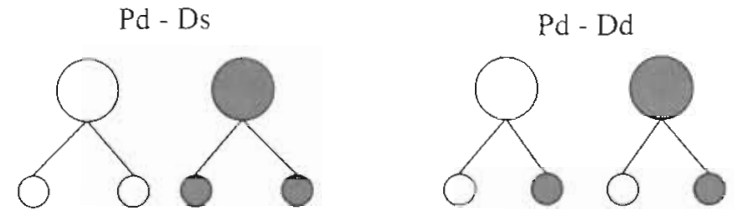

Fig. 9. Gymnodinium breve. A summary of the possible relationshups between parent (P) and daughter (D) cells that are biochemically the same $(s$, open circle) or different ( $d$, shaded circle)

continuously change through the light period. Since Gymnodinium breve can swim $1 \mathrm{~m} \mathrm{~h}^{-1}$, the cause of the extended delay in surface arrival is unclear. Interestingly, the surface samples showed a temporal pattern of biosynthesis that suggests active growth, while the mid-column samples did not. Pd-Ds, Ps-Dd and Pd-Dd, all of which provide different types of daughter cells (multi-cell mechanism), require that the more hiochemically deprived cells accumulate at the surface during the light period. In this less dynamic situation, the cells contributing to the surface aggregation may remain there together through the light period. The return to similar cellular biochemical averages at both depths each night may result either from the full redistribution of different cell types at both depths or from a vertical gradient of sub-population variances associated with nearly identical sub-population averages. Bulk measurements as reported here that provide only cellular averages need supplemental cell specific measurements from epifluorescence microscopy (Kohen \& Hirschberg 1989) or flow cytometry (Yentsch et al. 1986) to help distinguish among both the parent/daughter and descent distribution alternatives.

Hitchcock (1982) also developed caloric relationships as related to cell volume of the measured dinoflagellates based on the caloric equivalents (4.19 ncal $\mathrm{pg}^{-1}$ protein; 4.20 ncal $\mathrm{pg}^{-1}$ carbohydrate; and $9.50 \mathrm{ncal} \mathrm{pg}^{-1}$ lipid) obtained from Prosser \& Brown (1961) and verified for phytoplankton by Platt \& Irwin (1973). He multiplied each equivalent by the concentration of the appropriate constituent and summed the values. For each measured dinoflagellate species, he plotted these summed values against cell volume to yield the relationship, $\log$ ncal cell $l^{-1}=0.80 \log$ (volume) + $0.90, r=0.93$. The caloric values from this regression equation for the Gymnodinium breve cell volumes ( $d \times$ $d \times 5 \mu \mathrm{m}$ ), estimated as $2000 \mu \mathrm{m}^{3}$ from the cell diameters $(d)$ in Fig. 3, are in Fig. 10. Hitchcock's regression equation gives caloric values that are a simple function of cell volume and thus exactly follow the diel trend in cell diameter in Fig 3. The caloric values based on $G$. breve's constituent concentrations (Fig. 10) also vary with time of day. In addition, they reflect the behavioral redistribution of cells with different biochemical compositions. This segregation leads to cells with about twice the average constituent-based caloric value at mid-column as at the surface at 12:00 h. The constituent-based caloric value of the newly divided $G$. breve cells at mid-column on the first sample day is about half that predicted based on cell volume. This caloric value at both sample depths increases with time such that the mid-column approaches the predicted value at 18:00 h on the third day. The overall range of constituent-based caloric value for $G$. breve is 1500 to $4000 \mathrm{ncal} \mathrm{cell}^{-1}$. Though small compared to the range for all measured dinoflagellates $\left(10^{3}\right.$ to $10^{5}$ ncal cell $\left.{ }^{-1}\right)$ in Hitchcock (1982), a factor approaching 3 may still be significant for any grazers capable of feeding on this $\mathrm{HAB}$ species. Predation pressure on HAB species is a poorly known loss term potentially affecting their net growth. The difference among cells that is summarized in the caloric range may be a significant factor depending on how any predation pressure on $G$. breve is distributed among the different types of cells. For example, preferential loss of cells with higher caloric values

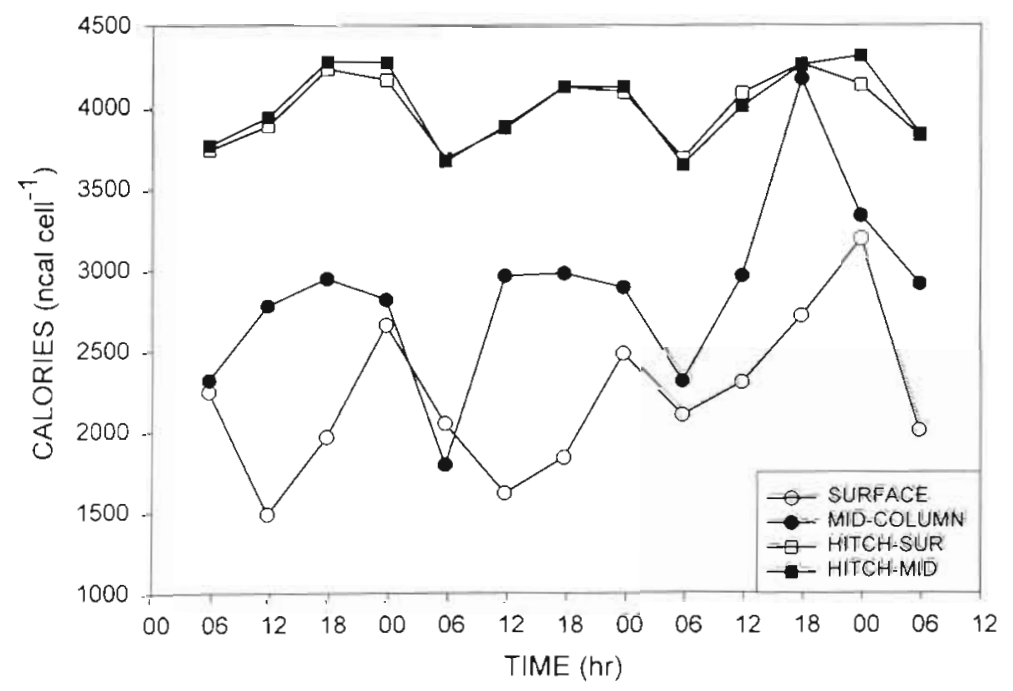

Fig. 10. Gymnodinium breve. Time course of the calculated caloric value of cells from the surface and mid-column based on carbohydrate, lipid and protein content compared to that calculated for the surface and midcolumn from the equation, logncalcel $)^{-1}=0.80 \log ($ volume $)+0.90(\mathrm{r}=$ 0.93), provided by Hitchcock (1982) based on an estimated cell volume of $2000 \mathrm{\mu m}^{3}$ 
may slow the net growth of $G$. breve populations under appropriate circumstances.

Cullen (1985) provided evidence based on Heterocapsa niei that dinoflagellate behavior and physiology combine to enhance growth. Near-surface carbohydrate synthesis during the day supports nitrogen uptake and assimilation deeper in the water column at night for protein synthesis. Crawford \& Dodge (1974) reported that dinoflagellates store both carbohydrate and lipid as food reserves, and this is true for Gymnodinium breve. In the present case, the strength of negative geotaxis in the mid-column sub-population inversely correlates with cellular lipid concentration. This correlation may be due to coincidental cycling of the 2 measurements, but it deserves further consideration in the context of the 2 orientation hypotheses dealing with mechanical and/or optimization influences on orientation (Kamykowski 1995). For example, the lipid distribution within cells as determined from targeted stains viewed with epifluorescence microscopy may support or contradict a mechanical influence on cell orientation.

Macintyre et al. (1997) expanded Cullen's (1985) hypothesis as a general nutritional model for dinoflagellate behavior, but noted that different species exhibit different responses to the same environment. In particular, some species continue to migrate in nutrient replete water columns, while other species stop migrating when nutrients are available at the surface. The present mesocosm nitrate concentration was about $150 \mu \mathrm{M} \mathrm{NO}_{3}-\mathrm{N}$ after the second renewal. The single large division on 22 July consumed about $24 \mu \mathrm{M} \mathrm{NO}_{3}$ $\mathrm{N}$ or $<20 \%$ of the available nitrate if all of the nitrate utilized came from the upper $12 \%$ of the mesocosm typically occupied by the surface aggregate. The growth conditions thus are considered nutrient replete. Unlike Alexandrium tamarense's lack of migration when nutrients are available at the surface, Gymnodinium breve aggregates at the surface during the day and disperses through the available water column at night. The behavioral responses of this species under more natural nutrient conditions representative of the West Florida shelf, USA, remain a high research priority.

Acknowledgements. Hidekatsu Yamazaki and Atsuko Yamazaki contributed to the theory that stimulated these laboratory experiments. Gary Kirkpatrick provided the culture of Gymnodinium breve. John Cullen provided information on the carbohydrate method. This work was supported by NSF grant OCE-9503253.

\section{LITERATURE CITED}

Berdalet E. Dortch Q (1991) New double-staining technique for RNA and DNA measurement in marine phytoplankton. Mar Ecol Prog Ser 73:295-305
Berdalet E, Latasa M, Estrada M (1992) Variations in biochemical parameters of Heterocapsa sp. and Olithodiscus luteus grown in 12:12 light:dark cycles. I. Cell cycle and nucleic acid composition. Hydrobiologia 238:139-147

Blasco D (1978) Observations on the diel mugration of marine dinoflagellates off the Baja California coast. Mar Biol 46 : $41-47$

Carretto Jl, Carrigan MO, Daleo G, Marco SG (1990) Occurrence of microsporine-like amino acids in the red-tide dinoflagellate Alexandrium excavatum: UV-photoprotective compounds. J Plankton Res 12:909-921

Chan AT (1978) Comparative physiological study of marine diatoms and dinoflagellates in relation to irradiance and cell size I. Growth under continuous light. J Phycol 14:396-402

Crawford RM, Dodge JD (1974) The dinoflagellate genus Woloszynskia II. The fine structure of $W$. Coronata. Nova Hedwigia 22:699-719

Cullen JJ (1985) Diel vertical migration by dinoflagellates: roles of carbohydrate metabolism and behavioral flexibility. In: Rankin MA (ed) Migration, mechanisms and adaptive significance. Contrib Mar Sci 27:135-152

Cullen JJ, Horrigan SG (1981) Effects of nitrate on the diurnal vertical migration, carbon to nitrogen ratio, and the photosynthetic capacity of the dinoflagellate Gymnodinium splendens. Mar Biol 62:81-89

Cullen JJ, Zhu M, Davis RF, Peterson DC (1985) Vertical migration, carbohydrate synthesis and nocturnal uptake during growth of Heterocapsa niei in a laboratory column. In: Anderson DM, White AW, Baden DG (eds) Toxic Dinoflagellates. Elsevier, New York, p 189-194

Dubois M, Gilles KA, Hamilton JK, Rebers PA, Smith F (1956) Colorimetric method for determination of sugars and related substances. Anal Chem 28:350-356

Eggersdorfer B, Hader DP (1991a) Phototaxis, gravitaxis and vertical migrations in the marine dinoflagellate Prorocentrum micans. FEMS Microbiol Ecol 85:319-326

Eggersdorfer B. Hader DP (1991b) Phototaxis, gravitaxis and vertical migrations in the marine dinoflagellates, Peridinium faroense and Amphidinium caterae. Acta Protozool 30:63-71

Eppley RW, Holm-Hansen O, Strickland JDH (1968) Some observations on the diurnal vertical migration of dinoflagellates. J Phycol 4:333-340

Flynn KJ, Flynn K, John EH, Reguera B, Reyero ML, Franco JM (1996) Changes in toxins, intracellular and dissolved free amino acids of the toxic dinoflagellate Gymnodinium catenatum in response to changes in inorganic nutrients and salinity. J Plankton Res 18:35-44

Frempong E (1982) The space-time resolution of phased cell division in natural populations of the freshwater dinoflagellate Ceratium hirundinella. Int Rev Ges Hydrobiol 67. $323-339$

Guillard RRL, Hargraves PE (1993) Stichochrysis immobilis is a diatom, not a chrysophyte. Phycologia 32:234-236

Harris GP. Heaney SI, Talling JF (1979) Physiological and environmental constraints in the ecology of the planktonic dinoflagellate Ceratium hirudinella. Freshwat Biol 9: $413-428$

Heaney SI, Eppley RW (1981) Light, temperature and nitrogen as interacting factors affecting diel vertical migration of dinoflagellates in culture. J Plankton Res 3:331-344

Heil C (1986) Vertical migration of Ptychodiscus brevis (Davis) Steidinger, MS thesis, University of South Florida, St. Petersburg

Hitchcock GL (1982) A comparative study of the size-dependent organic composition of marine diatoms and dinoflagellates. J Plankton Res 4:363-377 
Homma K, Hastings JW (1988) Cell cycle synchronization of Gonyaulax polyedra by filtration: quantized generation times. J Biol Rhythms 3:49-58

Homma K, Hastings JW (1989) Cell growth kinetics, division asymmetry and volume control at division in the marine dinoflagellate Gonyaulax polyedra: a model of circadian clock control of the cell cycle. J Cell Sci 92:303-318

Jones RI (1993) Phytoplankton migrations: patterns, processes and profits. Arch Hydrobiol Beih Ergeb Limnol 39:67-77

Kamykowski D (1981) Laboratory experiments on the diurnal vertical migration of marine dinoflagellates through temperature gradients. Mar Biol 50:289-303

Kamykowski D (1995) Trajectories of autotrophic marine dinoflagellates. J Phycol 31:200-208

Kamykowski D, McCollum SA, Kirkpatrick GJ (1988) Observations and a model concerning the translational velocity of a photosynthetic marine dinoflagellate under variable environmental conditions. Limnol Oceanogr 33:66-78

Kamykowski D, Reed RE, Kirkpatrick GJ (1992) Comparison of sinking velocity, swimming velocity, rotation and path characteristics among six marine dinoflagellate species. Mar Biol 113:319-328

Kamykowski D, Yamazaki H (1997) A study of metabolisminfluenced orientation in the diel vertical migration of marine dinoflagellates. Limnol Oceanogr 42:1189-1202

Kamykowski D, Yamazaki H, Yamazaki AK, Kirkpatrick GJ (1998) A comparison of how different orientation behaviors influence dinoflagellate trajectories and photoresponses in turbulent water columns. In: Anderson DM, Cembella AD, Hallegraeff GM (eds) The physiological ecology of harmful algal blooms. Springer-Verlag, Berlin, p $581-599$

Karentz D (1983) Patterns of DNA synthesis and cell division in marine dinoflagellates. J Protozool 30:581-588

Kemp PF, Sherr BF, Sherr EB, Cole JJ (1993) Handbook of methods in aquatic microbial ecology. Lewis Publishers, Boca Raton

Kessler JO, Hill NA, Hader DP (1992) Orientation of swimming flagellates by simultaneously acting external factors. J Phycol 28:816-822

Kim YS, Martin DF (1974) Effects of salnity an synthesis of DNA, acidic polysaccharide, and ichthyotoxin in Gymnodinium breve. Phytochemistry 13:533-538

Kochert G (1978) Quantitation of the macromolecular components of microalgae. In: Hellbust JA, Craigie JS (eds) Handbook of phycological methods: physiological and biochemical methods. Cambridge University Press, Cam-

Editorial responsibility: Otto Kinne (Editor),

Oldendorf/Luhe, Germany bridge, p 189-195

Kohen E, Hirschberg JG (1989) Cell structure and function by microspectrofluorometry. Academic Press, San Diego

Latasa M, Berdalet E, Estrada M (1992) Variations in biochemical parameters of Heterocapsa sp. and Olithodiscus Juteus grown in 12:12 light:dark cycles. II. Changes in pigment composition. Hydrobiologia 238:149-157

Levandowsky M, Kaneta P (1987) Behavior in dinoflagellates. In: Taylor FJR (ed) The biology of dinoflagellates. Blackwell Scientific, Oxford, $p$ 360-397

Lowry OH, Roseborough NJ, Farr AL, Randall RJ (1951) Protein measurement with the Folin phenol reagent. J Biol Chem 193:265-275

MacIntyre JG, Cullen JJ, Cembella AD (1997) Vertical migration, nutrition and toxicity in the dinoflagellate Alexandrium tamarense. Mar Ecol Prog Ser 148:201-216

Mitchell JG, Okubo A, Fuhrman JA (1990) Gyrotaxis as a new mechanism for generating spatial heterogeneity and migration in microplankton. Limnol Oceanogr 35:123-129

Parsons TR, Maita Y, Lalli CM (1984) A manual of chemical and biological methods for seawater analysis. Pergamon Press, Oxford

Peterson GL (1977) A simplification of the protein assay method of Lowry et al., which is more generally applicable. Anal Biochem 83:346-356

Platt T, Irwin B (1973) Caloric content of phytoplankton. Limnol Oceanogr 18:306-310

Prezelin BB (1992) Diel periodicity in phytoplankton productivity. Hydrobiologia 238:1-35

Prosser CL, Brown FA (1961) Comparative animal physiology, 2nd edn. Saunders, Philadelphia

Rizzo PJ, Jones M, Ray SM (1982) Isolation and properties of isolated nuclei from the Florida red tide dinoflagellate Gymnodinium breve (Davis). J Protozool 29:217-222

Sournia A (1974) Circadian periodicities in natural populations of marine phytoplankton. Mar Biol 12:325-389

Taylor FJR, Pollingher U (1987) Ecology of dinoflagellates. In: Taylor FJR (ed) The biology of dinoflagellates. Blackwell Scientific, Oxford, p 398-529

Tester PA, Steidinger KA (1997) Gymnodinium breve red tide blooms: initiation, transport and consequences of surface circulations. Limnol Oceanogr 42:1031-1059

Yentsch CM, Cucci TL, Phinney DA, Topinka JA (1986) Realtime chracterizations on individual particles at sea: flow cytometry. In: Bowman J, Yentsch M, Peterson WT (eds) Tidal mixing and plankton dynamics. Springer-Verlag, Berlin, p 414-448

Submitted: November 19, 1997; Accepted: March 6, 1998 Proofs received from author(s): June 3, 1998 